\title{
Cuerpo extraño vesical
}

\author{
I. Ascaso Cornago, D. Sánchez Zalabardo, J.Mª Cuesta Presedo \\ Servicio de Urología. Hospital Fundación de Calahorra. La Rioja.
}

Actas Urol Esp 2006; 30 (3): 341

$\mathrm{P}$ aciente intervenida hace 5 años de incontinencia urinaria de esfuerzo mediante la intervención de Burch vía abdominal.

Desde entonces infecciones urinarias de repetición se diagnostica mediante ecografía de cuerpo extraño intravesical, objetivándose mediante cistoscopia litiasis adherida a punto de sutura irreabsorbible.

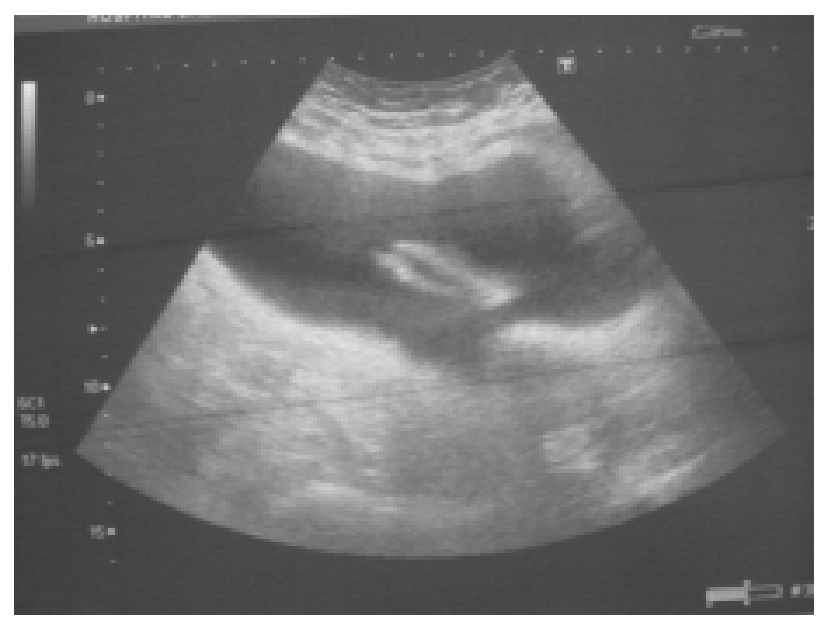

FIGURA 1
Se realiza corte endoscópico de la sutura y extracción de la misma y de la litiasis adherida.

Dr. I. Ascaso Cornago

E-mail: iascaso@fhcalahorra.com

(Trabajo recibido el 23 de noviembre 2005)

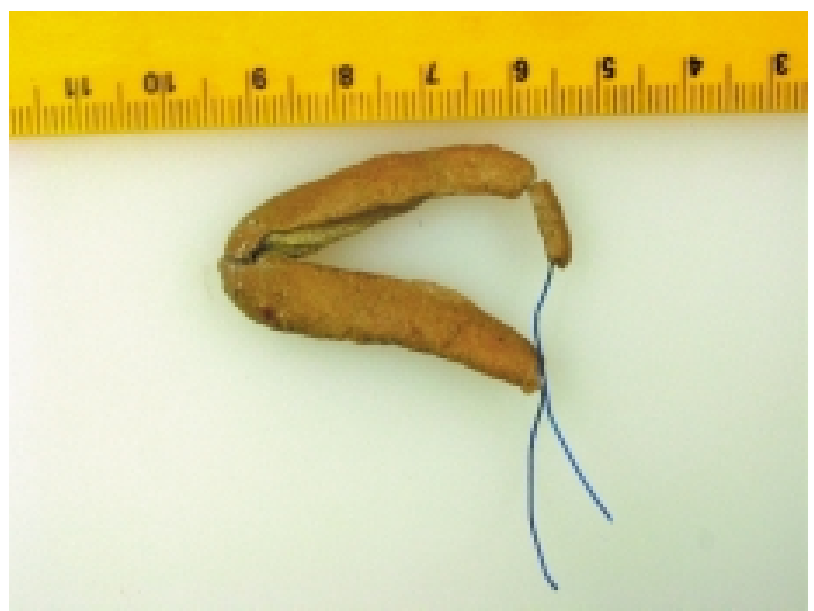

FIGURA 2 